\title{
SURVEY OF THE DIFFERENT URINARY INFECTIONS WHICH DEVELOP IN THE PARAPLEGIC AND THEIR RELATIVE SIGNIFICANCE
}

\author{
By J. W. McLeod, O.B.E., M.B.Glasg., F.R.S., \\ J. M. Mason, M.B.Edin. and R. W. K. NeILL, M.B.Manchester
}

AN investigation of the bacterial infections of the urinary tract in paraplegics has been carried out for the last four years at Edenhall Hospital in two wards which are reserved for patients suffering from spinal injury. The turn-over of patients in these wards is very slow and the total number of patients examined in this period was only 96. In a few cases only one examination was made and at the opposite extreme 75 or more. The majority, however, had 5 to 25 specimens examined. A factor of variation was that while a few patients were admitted within 3 to Io days of injury, others had been paralysed for 20 or more years, some in consequence of injuries suffered in the Second World War. The general investigation was directed especially to the following points:

(i) the variety of bacteria involved in the urinary tract infections of paraplegics and their relative importance;

(ii) the influence of these infections on the $\mathrm{pH}$ level of the urine and the separation of calcium salts;

(iii) the prevention of such infections and their cure, spontaneous or by medication;

(iv) evidence of symbiotic or antagonistic relationships between the different bacteria concerned.

Survey of Literature. There is, of course, an extensive literature which deals with many aspects of urinary infection in paraplegia. The general significance of infection has been amply explored, but less attention has been given to discriminating between the various types of infection and determining their relative significance. The chief points established in this literature are that infection is extremely common or even invariable. For Comarr (196I), infection is usually established when an indwelling catheter has been in situ for three days and often persists long after the catheter has been withdrawn.

Dick (1952), reviewing 178 cases treated at Winwick between 1940 and I948, found that although six different techniques were adopted, all were followed by infection. Talbot and Romsey (I955), did not find any patient free from infection among I20 paraplegics in the Peter Bent Brigham Hospital, although 37 of these were catheter-free.

Guttmann (1953), in a survey of the Second World War paraplegics, states that none of the 306 men who came to Stoke Mandeville having already had a suprapubic cystotomy escaped infection, and that even with intermittent catheterisation, which he recommended in the early stages, infection was invariable. Later, however, intermittent catheterisation has been continued until bladder function has been restored and the urine has been kept free from infection for many weeks (Guttmann, 1957; Colley \& Frankel, I963).

A second point on which there is general agreement is that the sequelae of infection of the urinary tract, especially the late sequelae, are the chief cause of fatalities among paraplegics. From a general survey of the literature Comarr (I96I) puts the mortality from renal disease in paraplegics as 27 per cent.

Damanski and Gibbon (1956), surveying a group of paraplegics over several years, found that among the 25 deaths which occurred, I 6 were due to uraemia, pyelonephritis being a contributory factor in 12 , calculus in 5 and reflux in 4 . 
D'Anonzio (1959), however, surveying 2 I patients who had carried indwelling catheters for Io years, found that the renal function of most was remarkably good but that in two who had carried catheters for 12 and 16 years respectively there was marked deterioration.

Morales and Tsou (1962), state that I3 per cent. of the 5743 veterans of the Second World War had died from urinary tract infections within nine years of spinal injury.

A limited number of investigators have explored the varieties of bacteria responsible for infection of the urine in paraplegia.

Talbot and Romsey (1955), examining I 20 cases and making I 39 cultures, got pure cultures of one species in II I and mixed ones in 28 . Among the pure cultures there were $53 \mathrm{~B}$. proteus, $23 \mathrm{~A}$. aerogenes, $\mathrm{1} 3 \mathrm{E}$. coli, 9 Ps. aeruginosa, and a miscellaneous group, mostly less common coliforms. Neither staphylococcus nor enterococcus are mentioned (one case with Strept. zymogenes).

Scott (1960), examining a series of I2I patients with neurological complications leading to paraplegia, found an overall incidence as follows: Coliforms 36 per cent., Strept. faecalis 23 per cent., B. proteus $2 \mathrm{I}$ per cent., Ps. pyocyanea Io per cent. and miscellaneous ro per cent.

His coliform group included $B$. coli 77 per cent., B. intermedium I 3 per cent. and $B$. aerogenes Io per cent.

The proteus strains included mirabilis, vulgaris and morganii, and of these 85 per cent. were mirabilis.

The miscellaneous group was mainly comprised of staphylococci, both coagulase negative and coagulase positive.

No clear evidence of antagonism or synergism among the different varieties of bacteria was discerned.

The only conclusion with regard to significance is that proteus infections were more associated with chronic and coliforms more with primary infections. S. faecalis and Ps. pyocyanea resembled proteus in this respect.

Guttmann (1953), discussing work done with collaborators, gives the following list of urinary infections: $B$. coli (including $A$. aerogenes), atypical $B$. coli, B. proteus, $B$. pyocyaneus, Staph. pyogenes, Strept. faecalis, micrococci and diphtheroids. The proportions in which these occur and their relative severities are not discussed except to say that the last three are probably insignificant and that where they alone appear the patient has been considered to be free from urinary tract infection.

Dealing with later experience at Stoke Mandeville Frankel and Colley (1936) discuss the merits of various antibiotics in the treatment of the urinary infection of the paraplegic and mention that they had dealt with 32 cases of Providencia infection among their patients. Such cases are also noted by Milner (1963).

The name B. providencia was suggested by Kaufmann (I95 I, I954) for a coliform strain first isolated and described by Stuart et al. (1943 I945, I946) in an outbreak of gastroenteritis in the city of Providence, Rhode Island, U.S.A., under the designation 'Paracolon Bacillus 299I I'. This micro-organism has since been found in many parts of the world in association with outbreaks of gastro-enteritis of moderate severity, Brooke (I95I), Brown (1952), Singer and Bar-Chay (1954) and Ridge and Thomas (1955). References to its appearance in the urinary tract have been less frequent, but Dutton and Ralston (1957) bring out the interesting point that in surgical wards they are found in some post-operative but not in pre-operative specimens of urine.

Morales and Tsou (I962), who differ from other observers in finding streptococci the most common urinary infection in paraplegics, often found para-colon bacteria and this group may have included $B$. providencia.

Methods Used. Some of these have already been described in a paper by Gould and McLeod (1960), which deals especially with bacteriological methods adopted in the 
recognition of Ps. pyocyanea, and in one by McLeod et al. (1963) in which the criteria for the existence of bacterial infection of the urinary tract are discussed.

Quantitative Estimates of the Weight of Infection. In view of the varying extent to which different bacteria are inhibited or favoured in different media and the tendency of one bacterium to favour or check the growth of another, it is obvious that an exact determination of the proportions in which bacteria are actually present in the urinary tract is difficult and would be impossible in the time available for the examination of I 5 to 30 specimens every week. The rough method adopted was therefore to spread a small drop of the centrifugal sediment, delivered with a fine capillary pipette, to each of three solid media in plates; heated blood agar, MacConkey's agar and 0.3 per cent. dettol agar respectively. A confluent growth over the whole plate was given a ${ }^{++}+$value and was represented by 30 small squares of the graph paper on which results were charted. A growth confluent on half the plate with scattered colonies on the other half was given a ${ }^{++}$and 20 square value and so on. The confluent growth with swarming proteus gave most difficulty since on agar or blood agar which was moist a moderate number of colonies might give rise to a confluent growth over the whole surface. This was controlled, however, by the MacConkey plate and the number of non-lactose-fermenting colonies which it carried. The differentiation between non-swarming proteus and other non-lactosefermenting colonies was overcome latterly by subculturing a selection of discrete colonies to plates of Christensen medium (1946) on which the urea-splitters were readily distinguished from bacteria which did not hydrolyse urea, after half to three hours' incubation. When growing on Christensen's medium $A$. aerogenes splits urea much more slowly than $B$. proteus and can be distinguished from the latter by the lower $\mathrm{pH}$ developed and much more abundant growth.

pH Estimations. These were done with the usual comparator-box after a preliminary test with a Universal indicator had shown whether methyl red, bromthymol blue, phenol red or cresol red would cover the appropriate range. Urines with reactions at the upper end of the cresol red range were tested with phenolphthalein and according to the strength of reaction assumed to be at $\mathrm{pH}: 9$ or beyond. From time to time a reaction was checked electrometrically with the $\mathrm{pH}$ meter. There were no serious divergences.

It is obvious that fluctuations in $\mathrm{pH}$ levels and in the number of living bacteria are liable to occur after the urine has left the bladder. This certainly does happen in urines heavily infected with $B$. proteus strains since these may give rise to rapid hydrolysis of urea and the development of high levels of $\mathrm{pH}, 9$ or more, which are bacteriostatic or bactericidal. It is therefore important that determinations of $\mathrm{pH}$ level and of the number of living bacteria present in the urine should be carried out soon after it has left the bladder.

Procedure in Catheter Management of Patients and Transfer of Urine Samples to the Laboratory. A few cases received uninfected had their catheters changed daily by procedures described by McLeod et al. (1963), as long as they remained uninfected. Samples were taken from the catheter before removal in these cases. Most patients had indwelling catheters which were connected by tubing to Winchesters fitted with metal screw-caps and containing adequate antiseptic to keep the content of the Winchester sterile. In collecting samples the cap was unscrewed and the urine allowed to run into the 'universal container' in which it was transmitted to the laboratory.

A rapid dispatch of specimens to the laboratory was made by the ward staff or by messenger sent from the laboratory and examination was carried out on receipt of the specimen. The usual interval between collection and examination of specimens was I5 to 45 minutes. There were, of course, a few exceptions.

Indwelling catheters were changed weekly unless blockage made it necessary after a shorter interval. 
On change of indwelling catheter, the bladder was washed out with I-5000 Hibitane the parts were cleaned up with I-IO0O stainless merthiolate and a fresh catheter was introduced by a non-touch technique; KY jelly was used for lubrication.

Midstream specimens were taken without special preparation and collected in 30-ml. screw-capped bottles.

Quantitative Estimates of Red Blood Corpuscles and Leucocytes. These estimates were based on the measurement by calipers of the centrifugal deposit from $5 \mathrm{ml}$, of urine in a round-bottomed tube, combined with an assessment of the cellular, bacterial and amorphous or crystalline elements in the deposit revealed by examination under oil-immersion lens of Leishman-stained films and in many cases also of wet preparations.

If operating in this way a deposit of $5 \mathrm{~mm}$. diameter or more is observed and polymorphonuclear leucocytes are readily distinguished in it by an experienced observer the urine is abnormal.

Exact quantitative estimates of both cells and bacteria in urine are much in vogue at the present day; but in the opinion of the authors subjection to statistical analysis of figures for the total content of nucleated cells in the urine has very little meaning when the polymorphs and non-squamous epithelial cells are not differentiated, as in the work, for example of Houghton and Pears (1957). It may be that more significant results will be obtained by the combination of counting-chamber and oxidase reaction, as in the very recent published work of Prescott and Brodie (1964). Work on the histological evidence for pyelonephritis repeatedly emphasises the recognition of polymorphonuclear leucocytes in the inflamed tissues as an essential criterion of this disease, for example McDonald et al. (1957) and Kimmelstiel et al. (1961).

In respect of bacterial counts significant bacteruria has been widely accepted as $10^{5}$ bacteria/ml. of urine, following the work of Kass (1955), Kass and Sossen (1959), corroborated by Brumfitt et al. (I96I) and many others. However true this may be for midstream specimens of urine taken from selected groups of co-operative adults who are physically fit, it leads, when applied to samples of urine obtained from young children or from adults who are gravely ill, to erroneous conclusions and ill-directed antibiotic therapy. This is indicated by the comparison of catheter and 'midstream' or clean catch specimens as in the work of Pryles et al. (196I) and in our own on paraplegic patients, and on children (Braude \& McLeod, unpublished).

In these estimations of the cell-content of urine Bacillus proteus is a source of difficulty since in the highly alkaline urine with which it is often associated the cells undergo disintegration and stain poorly. The levels shown for blood cells in the more active proteus infections are therefore probably unduly low, and may well account for some of the findings of bacteruria without associated pyuria which are reported in the literature.

Casts and Crystals. The appearance of casts was rare in this series of cases but was particularly significant in two cases, to which reference will be made later. Triple phosphates were repeatedly recognised in cases of proteus infection, but in view of the extensive use of sulphonamides, antibiotics, etc., and the appearance of some of these in various crystalline forms in the urine it was not considered useful to record the appearance of crystals without making an elaborate study of those likely to be derived from drugs.

Antibiotics. All antibiotics administered have been entered at the top of the charts and indicated by an initial letter or letters. The period of administration is indicated directly in Charts 3 and 4 and in days by numbers in Charts $I$ and 2.

Dosage has been I mega unit per diem in two doses for crystamycin and penicillin and I gramme per diem in four doses for chloromycetin, tetracycline and kanamycin. 


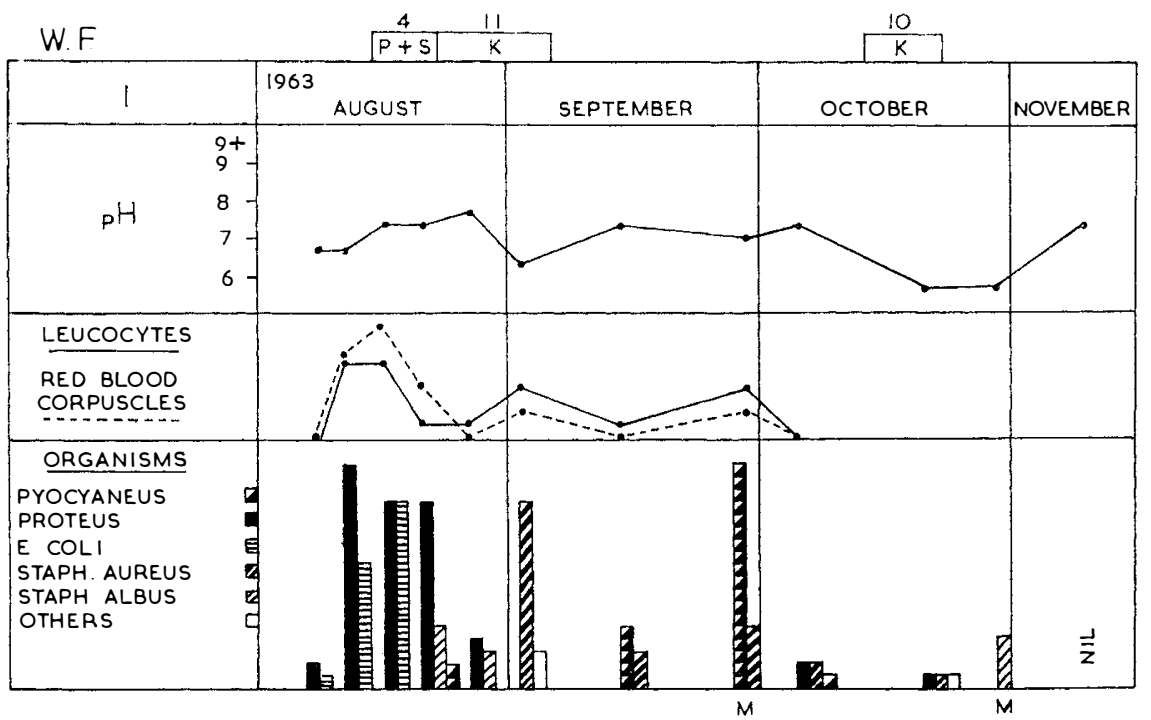

D.W. 3
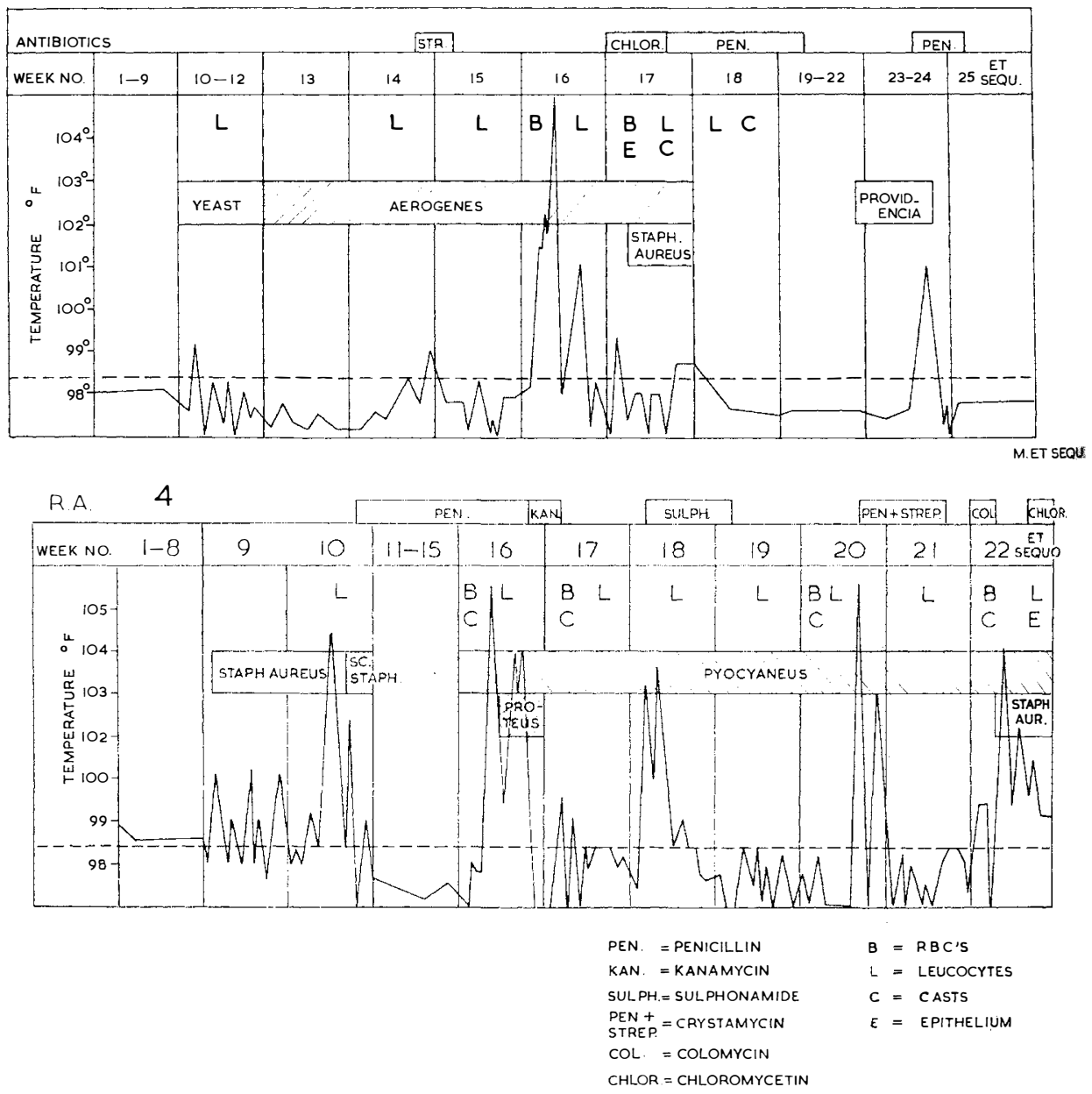


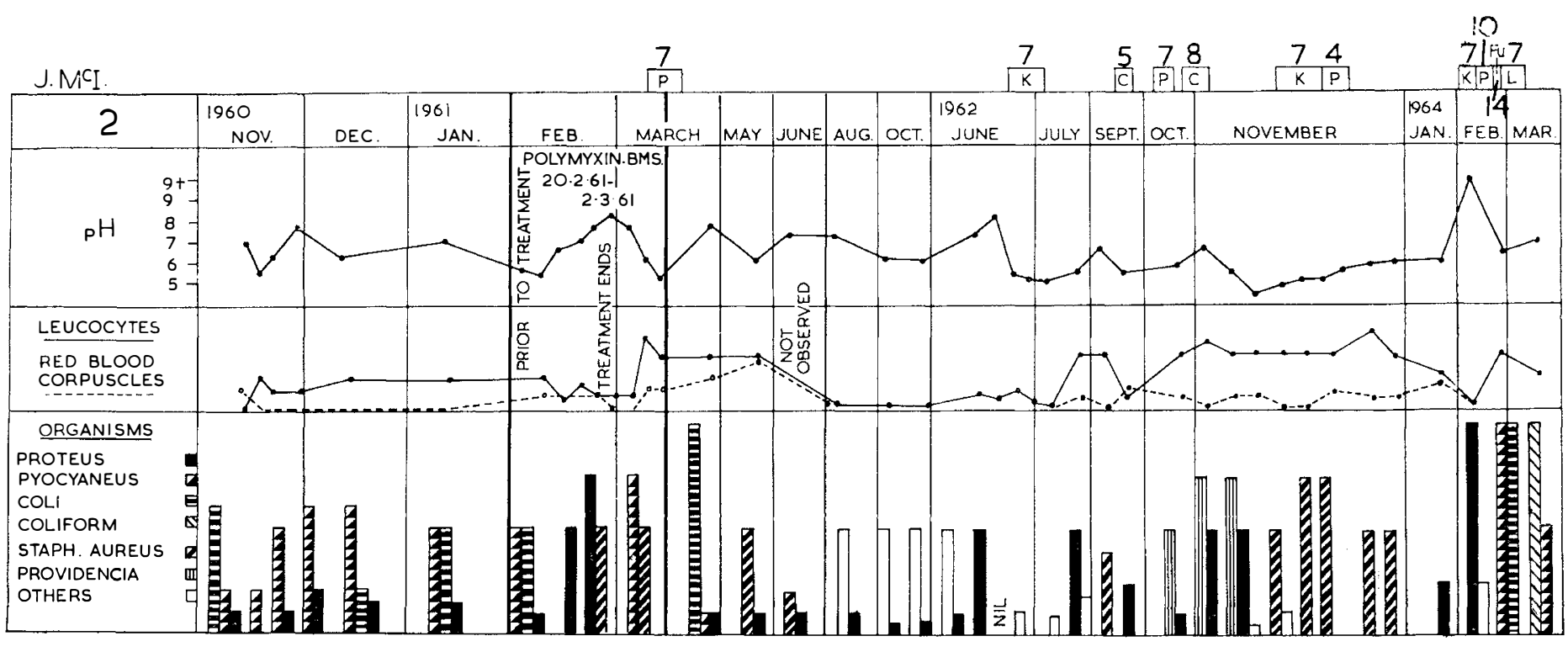




\section{RESULTS}

The Extent to which Infection of the Urinary Tract occurs in Paraplegia. The answer to this question in so far as this series of cases and other published series give it, is that where an indwelling catheter is used and left in situ, all become infected in 2 to 12 days. This has been observed even in a patient admitted with uninfected urine and before removal of the Gibbon catheter (I958), introduced soon after injury.

With the exception of rare cases which reached Edenhall within a few days of injury, the urine was found to be infected irrespective of the hospital from which the patient came, and patients whose urine was faultless or only showed trivial infection when first admitted were usually found to be infected after the catheter with which he or she arrived had been withdrawn. It is, of course, possible that this was due to infection arising from an inadequate technique in the wards at Edenhall, but it seems much more likely that bacteria present high in the urethra owing to a urethritis set up by the presence for a week or more of a foreign body, the catheter, are carried up to the bladder when the second catheter is introduced.

Actually the only patients who have escaped infection altogether or had no more than a trivial one have been $(a)$ those who owing to an incomplete lesion have not required a catheter or only needed one for a short period, $(b)$ one whose bladder was emptied by heavy external pressure until he was educated to control it.

Variety of Bacteria which cause Infection of the Urinary Tract in Paraplegics and their Relative Importance. All the patients had their urinary infections, the appearance of blood and leucocytes in the urine and its $\mathrm{pH}$ set out in a series of charts to facilitate correlation of these observations. Charts I and 2 are reproduced to indicate the kind of record which resulted, but Charts 3 and 4 were designed to show correlation of infection and fever and omit observations of $\mathrm{pH}$ level. The bacteria which appeared with sufficient frequency to merit discussion of their relative importance as sources of infection were the following: Aerobacter aerogenes, Bacillus proteus (mostly Proteus mirabilis), Enterococcus, Escherichia coli, Bacillus providencia, Pseudomonas pyocyanea, Staphylococcus aureus (coagulase positive), Staphylococcus albus, yeast, diphtheroids and some unclassified coliforms. When the bacteria are placed in the order of the number of cases in this series in which they appeared at one time or another, the order was found to be as given in Table I.

TABLE I

\begin{tabular}{|l|l|}
\hline \multicolumn{1}{|c|}{ Bacterium } & \multicolumn{1}{|c|}{ All cases (96) } \\
\hline B. proteus & appeared in 70 per cent. \\
Ps. pyocyanea & appeared in 54 per cent. \\
E. coli & appeared in 36 per cent. \\
A. aerogenes & appeared in 35 per cent. \\
B. providencia & appeared in 30 per cent. \\
Enterococcus & appeared in 29 per cent. \\
Staph. aureus & appeared in 23 per cent. \\
Staph. albus & appeared in 6 per cent. \\
\hline
\end{tabular}


There was no clear indication that the diphtheroid bacilli were a source of inflammation. It appears from Chart 3 that yeasts may excite a mild inflammatory reaction but their incidence in the series was low and they appeared to be readily replaced by bacteria.

The abundance of the bacteria in the cases in which they appeared was taken into account as well as the percentage of cases in which they occurred. The chief result of such an assessment was to give additional emphasis to the part played by $B$. proteus and Ps. pyocyanea and to indicate an even lesser role for the staphylococcus.

As the number of female cases was small, I5, the minor contrasts between incidence of infection in the sexes need not be considered. A markedly higher rate of $E$. coli infection in the female is probably significant.

Persistence of Infection. In estimating this the numbers of cases in which each bacterium appeared as an initial and as the latest observed infection were compared:

TABLE II

\begin{tabular}{|l|c|c|c|}
\hline Bacterium & $\begin{array}{c}\text { Early infection } \\
\text { as percentage of } \\
\text { total infection }\end{array}$ & $\begin{array}{c}\text { Late infection } \\
\text { as percentage of } \\
\text { total infection }\end{array}$ & $\begin{array}{c}\text { Ultimate percentage } \\
\text { increase or decrease } \\
\text { of infection }\end{array}$ \\
\hline Ps. pyocyanea & 39 & 55 & $+\mathrm{I} 6$ \\
Aer. aerogenes & $2 \mathrm{I}$ & 30 & 9 \\
B. proteus & 56 & 62 & +6 \\
Staph. aureus & 36 & 36 & No change \\
Enterococcus & $4 \mathrm{I}$ & $4 \mathrm{I}$ & No change \\
B. providencia & 43 & 36 & -7 \\
E. coli & 62 & $4 \mathrm{I}$ & $-2 \mathrm{I}$ \\
\hline
\end{tabular}

The figures are too small to permit of firm conclusions but the indications suggested are that pyocyaneus, aerogenes and, to a lesser extent proteus infections tend to persist and that $E$. coli and to a less extent providencia infections tend to disappear. The factors which are likely to operate in producing sequences of different infections are, however, very complex. Among these are exposure to reinfection, the susceptibility of the infections to the antibiotics administered to the patients, the ability of one strain of bacterium to eliminate another when they are in competition in the urinary tract or conversely their capacity for symbiosis, the development of immunity to an infection developed in the tissues of the host, and in all probability peculiarities in the metabolism of the host such as those leading to unusually low $\mathrm{pH}$ levels in the urine.

Other Evidences of the Relative Severity of Different Bacterial Infections in Paraplegia. Such evidence was sought $(a)$ in the presence of blood in the urinary sediment in infections with different types of bacteria; $(b)$ in the amount of pus in the urinary sediment, and $(c)$ in the correlation between fever and weight of infection with different types of bacteria. 
Correlation of Appearance of Blood and Pus in the Urinary Sediment with Different Types of Infection. A good deal of information on the subject is provided by the charts in this paper. A factor of difficulty in these correlations already referred to is the disintegrating effect of highly alkaline urines on both red and white blood corpuscles. Other factors are that trauma to the viscera related to the original injury may be responsible for blood present in the urine of patients admitted soon after injury. Also in the female a M.S.U. may occasionally contain traces of menstrual blood. It has therefore to be taken into account that in the case of heavy proteus infections the figures for both blood and leucocytes may be unduly low. The two considerations mentioned above as possible sources of error in assessing the significance of blood in the urine as an indication of the severity of infections by any given type of bacterium should operate equally for all infections unless some types of infection are more common in females than in males. This was the position as regards $E$. coli infections for which the incidence was more than twice as high in females as in the whole series.

\section{TABLE III}

\section{Correlation of Haematuria with Different Infections}

\begin{tabular}{|c|c|c|c|c|}
\hline $\begin{array}{l}\text { Predominant } \\
\text { infection }\end{array}$ & $\begin{array}{l}\text { Cases } \\
\text { recorded }\end{array}$ & $\begin{array}{c}\text { Percentage } \\
\text { showing positive } \\
\text { correlation }\end{array}$ & $\begin{array}{c}\text { Total } \\
\text { number of } \\
\text { examinations }\end{array}$ & $\begin{array}{c}\text { Percentage } \\
\text { showing positive } \\
\text { correlation }\end{array}$ \\
\hline Ps. pyocyanea & 32 & 59 & 77 & 43 \\
\hline $\begin{array}{l}\text { Staph. aureus } \\
\text { (coagulase } \\
\text { positive) }\end{array}$ & I I & 45 & 30 & 40 \\
\hline E. coli & 25 & 52 & 59 & 27 \\
\hline Enterococcus & 8 & 25 & II & 36 \\
\hline B. providencia & 24 & $4 \mathrm{I}$ & 62 & I8 \\
\hline B. proteus & 49 & 37 & I42 & $2 I$ \\
\hline A. aerogenes & 28 & 25 & 55 & 27 \\
\hline
\end{tabular}

In Table III the percentage showing positive correlation (column 3) indicates the proportion of patients carrying the infection named who showed haematuria on one or more occasions when that infection was dominant, and column 4 shows the total number of examinations made when that infection was dominant.

The percentage showing positive correlation (column 5) means the percentage of all examinations made on occasions when the named infection was dominant which revealed haematuria.

The order in which the different infections appear in the above table is determined from considering the results in columns 3 and 5. Similar correlations were worked out for pyuria and showed that it occurred in 80 to Ioo per cent. of all cases with the exception of those due to $B$. proteus, which were lowest at 67 per cent.

Association of Fever with the Infection. The development of fever is a generally recognised sequel to the invasion of the human body by pathogenic 
bacteria but not at all stages a feature of such invasion. The frequency with which the presence of a bacterium in the urinary tract is associated with febrile manifestations, however, is a valuable indication of its pathogenic role in that tract.

The correlation of infection with fever has therefore been investigated in two ways:

(a) A positive correlation was recorded if at any stage in the infection a heavy incidence of the bacterial species in question had been shown to correspond to a record of fever on the patient's temperature chart, irrespective of the simultaneous presence of other species of bacteria. Such correlations were recorded as a percentage of all patients infected with that bacterium.

(b) All heavy infections with the bacterium under consideration which occurred in the absence of any other infection unless a trifling one were recorded as positive if associated with fever and negative in the absence of fever.

The assessment under these two schemes are the bases of the statements made about correlation of fever and infection in Table IV. The assessment under scheme $(b)$ was similar to that under $(a)$ except that $B$. proteus appeared to be less, and $B$. providencia more, closely associated with fever.

\section{TABLE IV}

\begin{tabular}{|c|l|}
\hline \multicolumn{1}{|c|}{ Infection } & \multicolumn{1}{|c|}{ Characteristics } \\
\hline Ps. pyocyanea & $\begin{array}{l}\text { 6I per cent. correlation with fever. } \\
\text { High incidence and persistence. } \\
\text { Haematuria and pyuria frequent. }\end{array}$ \\
\hline B. proteus & $\begin{array}{l}\text { 5o per cent. correlation with fever. } \\
\text { Very high incidence. } \\
\text { Outstanding in producing alkaline urine with } \\
\text { separation of calcium salts. }\end{array}$ \\
\hline B. providencia & $\begin{array}{l}\text { 5o per cent. correlation with fever. } \\
\text { Moderate incidence and persistence. } \\
\text { Pyuria frequent: tolerant of high pH levels. }\end{array}$ \\
\hline Aer. aerogenes & $\begin{array}{l}\text { 23 per cent. correlation with fever. } \\
\text { Moderate incidence but considerable persistence. } \\
\text { Association with pyuria and haematuria low. }\end{array}$ \\
\hline Esch. coli & $\begin{array}{l}\text { 25 per cent. correlation with fever. } \\
\text { Moderate incidence and low persistence. } \\
\text { Association with pyuria and haematuria considerable. }\end{array}$ \\
\hline Staphylococcus & $\begin{array}{l}\text { 6o per cent. correlation with fever. } \\
\text { Low incidence. } \\
\left.\text { (coagulase }{ }^{+}\right)\end{array}$ \\
\hline High association with pyuria and haematuria. \\
\hline Enterococcus & $\begin{array}{l}\text { Incidence low and correlation with fever not } \\
\text { attempted. } \\
\text { Considerable association with pyuria and haematuria. }\end{array}$ \\
\hline & \\
\hline &
\end{tabular}


Summary with regard to significance of the Different Types of Infection. If frequence and weight of infection are taken into account the bacteria fall into the following order of importance:

Proteus species $>$ Ps. pyocyanea $>$ Aer. aerogenes $>$ E. coli $>$ B. providencia $>$ Staph. aureus $=$ Enterococcus.

If, however, their order of importance is determined by the evidence of pathogenicity derived from their association with fever, haematuria, pyuria and persistence of infection, a different order is suggested:

Ps. pyocyanea $>$ Staph. aureus $>$ Enterococcus $>$ B. providencia $>$ Proteus species $=$ Aer. aerogenes $>E$. coli.

The chief significance of the different bacteria is set out in Table IV. It is of course obvious that the position of infections in such a scheme will be in part affected by their sensitivity to the antibiotic and other remedial agents most used, and this may in some part explain the prominence of pyocyaneus and the lesser role of $E$. coli in this group of infections.

The Relation of the Different Infections to $\mathbf{p H}$ Levels in the Urine. It is in this connection that some of the findings have been so consistent as to be undoubtedly significant.

Observations on 50 patients over considerable periods in which infection was absent or very slight showed ranges of $\mathrm{pH}$ level between 4 and $7 \cdot 4$ with an average $\mathrm{pH}$ value of $5 \cdot 8$. Taking, therefore, $\mathrm{pH}$ values of 5 or less as unusually acid urines we find such values to be characteristic of infections with $E$. coli or Aer. aerogenes. Urines with high $\mathrm{pH}$, i.e. 8 or $>8$ were very constantly associated with proteus infections or mixed infections in which $B$. proteus was prominent. Thus there was a very strong correlation between high reactions, 8.5 to 9 or beyond, and the presence of $B$. proteus. This association of high $\mathrm{pH}$ and proteus infection is obviously important and is accompanied in most cases by a heavy secretion of mucus, the separation of triple phosphate crystals and considerable disintegration of leucocytes and red blood corpuscles. Sanford et al. (1956) note the common association of proteus infection, alkaline urine and the absence of pyuria.

An obvious and simple explanation of the highly alkaline urine in proteus infected patients is the capacity of these bacteria to produce urease which hydrolyses urea to ammonia. In a few cases high alkalinity of the urine persists over many months but more often it is a phase in a proteus infection and is preceded or followed by periods in which the proteus is present in smaller numbers and associated with other bacteria and a considerably lower level of $\mathrm{pH}$.

It is difficult to explain why a proteus infection once established in the urine fails to produce a persistently alkaline reaction. Such failures were frequently observed. If the urine of patients with proteus infection is examined within five minutes of voiding, many show $\mathrm{pH}$ levels within the range of 6.5 to 7.5 , but on standing develop high values 8.5 to 9 . This development of high alkalinity has not been observed in the absence of $B$. proteus but develops with varied rapidity in different specimens in which that bacterium is present and is rarely absent after the specimen has stood on the bench overnight. Factors which control this change may be the presence of other bacteria which check the growth of $B$. proteus or use the $\mathrm{NH}_{3}$ split from urea as a source of nitrogen; but stagnation appears to be the most important factor. 
It is likely that stagnation also operates in an important way in the urinary tract and that in pockets at the base of the bladder and elsewhere levels of $\mathrm{pH}$ exist which are not indicated by mid-stream samples. Evidence of this was obtained in a case of paraplegia examined recently in which several samples taken as the urine flowed freely from a catheter and examined forthwith showed the presence of $B$. proteus in large numbers, $\mathrm{pH}$ values of $7 \cdot 3$ but few if any recognisable leucocytes. The last 2 or $3 \mathrm{ml}$. of urine voided, however, consisted of thick muco-pus, loaded with triple phosphate crystals and showing a high $\mathrm{pH}$ level.

Relation of Variety of Bacterial Infection to Formation of Stone or Incrustation. Although there are many references to the association between stone formation and proteus infection of the urine in the literature there are relatively few publications in which emphasis is laid on the fact that the conditions which lead to the separation of calcium salts are produced more constantly by the proteus group of bacteria than by any other and that consequently they have a unique role in the formation of stone and incrustation.

Thus Damanski (1963), discussing stone formation in the urinary tract in paraplegia, mentions urea-splitters such as B. proteus as contributing considerably to the full growth of stones and Colley and Frankel (1964) mention the frequent occurrence of stone formation in Proteus mirabilis infections, but only as an explanation of the difficulty of antibiotic treatment of such infections.

If reference is made to recent editions of some of the well-known textbooks of surgery it is found that Badenoch (1958) states that the stone in infected urine is usually composed of triple phosphates and due to Staph. albus or B. proteus. Rose and Carless on the same subject (I960) state that phosphatic renal calculi are usually due to B. proteus or Staphylococcus: Handfield-Jones and Porritt (1957) mention Staphylococcus, B. proteus, Streptococcus and B. typhosus as appearing in alkaline infected urine. Finally, Bailey and Love (I962) generalise on the role of ureasplitting bacteria in the generation of stones, mentioning Streptococcus, Staphylococcus and Proteus.

Aird (1957), however, in discussing alkaline-encrusting cystitis, gives a more convincing description of the role of $B$. proteus and the importance of this microorganism in stone production had already been emphasised by Stol (I945).

The point which we wish to riake is that an established proteus infection means that the patient concerned is at once menaced with stone formation.

It is generally recognised that the stones which appear in the urinary systems of paraplegics are rather soft stones in which the principal constituent is $\mathrm{Ca}, \mathrm{Mg}, \mathrm{NH}_{4}$, phosphate or triple phosphate: Comarr et al. (I96I), Damanski (I963).

Williams (1963) states that such stones are formed on a muco-protein matrix and that two out of six examined in children were found to be associated with proteus infection. He does not mention any bacteriological detail in relation to the others.

When, therefore, proteus infection produces a highly alkaline urine the conditions required for stone formation are established, i.e. urine with a high content of mucus in which triple phosphate crystals and amorphous phosphates are separating.

The view suggested in much of the literature that a variety of urea hydrolysing bacteria are of equal importance in promoting stone formation is not supported by closer investigation, in our experience. When grown in Christensen's (1946) urea 
medium proteus strains develop a reaction so alkaline that it markedly inhibits their own growth. On the same medium staphylococcus and Aerobacter aer. produce a slower and less extreme change of reaction and grow relatively well.

In all 96 cases $\mathrm{pH}$ levels and varieties of bacterial infection were recorded. The charts often showed close correlation between high $\mathrm{pH}$ values and heavy proteus infection but rarely a similar correlation for other bacterial infections except when they were associated with proteus as a mixed infection.

To sum up, the conditions favourable to stone formation were frequently produced in the presence of proteus infection but seldom in that of Staphylococcus or other bacteria.

Actual Observations of Formation of Stone and Incrustation. Total cases 96, of which 2 I developed stone and one incrustation only: that is to say a 23 per cent. incidence of calculus or calcareous deposit in the series. This compares unfavourably with the rates recorded by Dick (1952) at Winwick- 9.6 per cent. in a series of 178 cases, and with the figure of Comarr et al. (I96I) who observed an 8.2 per cent. incidence of stone among I507 patients handled between I94I and I960 at Cleveland, Ohio. It corresponds, however, very closely to the Stoke Mandeville figures where Guttmann (1953) records a 22.5 per cent. incidence of stone among 350 paraplegics of the Second World War. Damanski and Gibbon (1956) record 20 per cent. incidence of stone in the 25 paraplegic deaths occurring in their series of cases.

The cases can be divided into three groups:

Group I. Cases in which a stone had developed prior to the initiation of bacteriological investigations. There were seven of these and all showed proteus infections subsequently during some part of the period of observation. Three of these showed considerable incidence of pyocyaneus at one stage and one showed a providencia infection. Staphylococcus, E. coli and Aer. aerogenes were not found to be abundant at any stage in these investigations.

Group II. Four cases in which stone formation occurred during the period in which bacteriological observations were made but which did not show a close correlation between periods of heavy proteus infection and the appearance of stones. At the time of stone formation one of these showed a considerable pyocyaneus infection and another showed a combined staphyloccocus and providencia infection.

Group III. Eleven cases in which there was a heavy proteus infection at the time of appearance of stones or in the six months prior to such appearance.

There were six which also showed pyocyaneus in these periods, two aerogenes, three staphylococcus, two E. coli and two providencia.

Summary. In every case in which the appearance of stone was recorded there was also a record at one time or another of proteus infection. In seven of these the record of stone formation was in a period when no bacteriological examinations were being made. Of the remaining I 5, I I showed a close correlation between heavy proteus infection, highly alkaline urine and the development of stone. But there were four in which this corre lation was less obvious.

There was one case in which a heavy incidence of pyocyaneus was recorded at the time of stone formation and another in which a combined staphylococcus and providencia infection coincided. 
All the other instances in which pyocyaneus, staphylococcus, aerogenes, E. coli and providencia were numerous at the time of stone formation coincided with heavy proteus infection.

There was, therefore, a close connection between proteus infection and stone formation which, in the cases recorded, was not observed with any other bacterium.

Attempts at Treatment of Established Infection. Very little systematic work was attempted in the treatment of these infections such as the comparison of two groups of patients with similar infections receiving different antibiotics. In four years the patients were under a number of clinicians and a wide range of remedies was administered in the course of their treatment. We have, however, two groups of observations which may throw some light on the general problem of treatment of such infections. These are the records of drugs given and the continuous records of the infections appearing in the urine of patients.

This permits of a very rough correlation of the disappearance of bacteria and changes of infection under the influence of the antibiotics and other medicaments tested.

Among these infections the data accumulated suggest that Ps. pyocyanea is the most difficult to eliminate and $E$. coli the easiest.

In view of the frequent appearance of penicillin-resistant strains of staphylococcus in hospitals in recent years, a point of considerable interest was that the great majority of the staphylococcal strains isolated were sensitive to penicillin and that this antibiotic was responsible for a number of our most satisfactory results. This is illustrated in Chart 3. Frankel and Colley (1963) and Colley and Frankel (1964) have drawn attention to the value of penicillin in providencia infections.

The antibiotics administered seem to have been at best responsible for the substitution of one infection by another during the period in which the catheter was retained, but more successful in the catheter-free period. Hence the removal of the catheter appears to have been an important factor in cure of infection.

Analysis of the Cases in this Series in which a Final Return to a Urinary Tract free from Infection has apparently been achieved. A combination of several factors has probably operated in some of these cases in which suitable therapy may have been combined with light infection or spontaneous tendency to recover.

There were 28 patients in the whole series of 96 whose urine was free from pus and bacteria when they left hospital, or later when they were examined as outpatients. A few relapses which may have been due to reinfection are recorded. The others have remained free from infection in so far as it has been possible to observe them. These cases are divided into three groups:

Group I. Those who never had an indwelling catheter-there were II of these. Infections were slight and included staphylococcus, enterococcus, proteus and providencia.

Group II comprised single dominant infections which disappeared. There were two $E$. coli infections and in one of these and also in a third case infected with proteus the cure appeared to be effected by chloromycetin. The fourth patient (Chart 3) had two separate infections: Aer. aerogenes which yielded to chloromycetin, four days, followed by three weeks' penicillin. Four 
weeks later he contracted a providencia infection which cleared after a fourweek course of penicillin. He has remained clear of infection now for I2 months.

Group III. This group includes I3 cases in which more than one infection occurred and is recorded in Table V.

Prophylaxis. It is indicated in what has been said above that cure of an established infection of the bladder in a paraplegic patient is a matter of great difficulty. It is clear therefore that the prevention of infection should be achieved if at all possible. This has already been discussed in the paper published by McLeod et al. (1963) which supports Guttmann's contention (1953, 1957, I96I) that infection of the urinary tract is diminished or prevented by intermittent catheterisation and frequent changes of catheter.

Using Ps. pyocyanea as an indicator micro-organism since it is rarely a commensal in the urinary tract (McLeod, 1958) and can be considered a ward infection, it has been demonstrated that this bacterium is found from time to time on the hands of nursing orderlies and of patients. Since there is no agent likely to be tolerated by the skin and suitable for rapid sterilisation of hands so infected (McLeod \& Taylor, I963), it follows that all procedures of catheterisation and adjustment of tubing connecting catheters to drainage bottles should be made with hands protected by sterile gloves, as has been emphasised by Pyrah et al. (1955), or under antiseptic precautions.

The storage of urine bottles in tanks of antispetic was recommended by McLeod (1958), and the charging of collecting receptacles with antiseptic adequate to maintain sterility in the urine which accumulates has been repeatedly emphasised (Riches, I955; Tagart, I956; Dutton \& Ralston, I957), and is commonly adopted.

If urine is withdrawn at rather long intervals and indwelling catheters abolished, the restoration of the bladder to automatic function may be more difficult on account of occasional over-stretching of the muscle fibres and consequent loss of tone (Murnaghan, I96I). The repeated catheterisation under very fastidious measures of technique as described by Guttmann (1953) or change of catheter every 24 hours with antibiotic lavage of the urethra as practised with some cases at Edenhall do involve a heavy load on the staff competent in these operations. They may be required at unusual times in dealing with emergencies, and have in any case to be continued without intermission for a period of weeks or even months.

Prophylaxis of infection is therefore very exacting but well worth while. In most hospitals it will require a reinforcement of trained personnel.

Possible Influence of Bacterial Antagonisms on the Disappearance of Bacteria from the Urinary Tract. A limited number of observations indicating this possibility were made. It would reasonably be expected that the bacteria which showed greatest persistence would be found to replace others-such are Ps. pyocyanea and Aer. aerogenes.

How far it may be possible to utilise some of these bacterial antagonisms is doubtful, but it would seem possible that the artificial substitution of one of the organisms most difficult to control by antibiotics, for example Ps. pyocyanea, with a hardy micro-organism of lesser antibiotic resistance such as Aer. aerogenes, might be followed by the elimination of the latter by a suitable antibiotic such as Kana- 
TABLE V

\begin{tabular}{|c|c|c|c|c|c|c|c|c|}
\hline Case & Hospital & Infection & $\begin{array}{l}\text { Catheter } \\
\text { removed }\end{array}$ & $\begin{array}{l}\text { State on } \\
\text { dismissal }\end{array}$ & \multicolumn{2}{|c|}{ Result on review } & Treatment & Summary \\
\hline I. $\mathrm{B}$. & $\begin{array}{l}27.9 .60 \\
\text { to } \\
7.11 .61\end{array}$ & $\begin{array}{l}\text { Proteus; Prov; } \\
\text { Aer; Pyo }\end{array}$ & Dec. I 960 & Infected & $\begin{array}{l}\text { Sept. } 1963 \\
\text { June } 1964\end{array}$ & $\begin{array}{l}\text { Clear } \\
\text { Proteus } \\
\text { Pyo }\end{array}$ & Nil & $\begin{array}{l}\text { (i) Cleared } \\
\text { (ii) Reinfected on } \\
\text { readmission and } \\
\text { reinsertion of catheter }\end{array}$ \\
\hline 2. F. & $\begin{array}{c}7.8 .63 \\
\text { to } \\
22.11 .63 \\
\end{array}$ & $\begin{array}{l}\text { E. coli; Staph; } \\
\text { Proteus; Aer }\end{array}$ & Sept. 1963 & Clear & None & None & $\begin{array}{l}\text { Last antibiotic } \\
\text { Kanamycin } \\
13-23.10 .63\end{array}$ & Cleared \\
\hline 3. W. R. & $\begin{array}{l}3.10 .60 \\
\text { to } \\
2.9 .61 \\
19.2 .62 \\
5.9 .63\end{array}$ & $\begin{array}{l}\text { Entero; Aer. } \\
\text { Proteus; Prov } \\
\text { Pyo }\end{array}$ & Mar. I96I & Clear & $\begin{array}{l}\text { May 1 } 962 \\
\text { Sept. } 1963 \\
\text { Oct. } 1963\end{array}$ & $\begin{array}{l}\text { Pyo } \\
\text { Proteus } \\
\text { Pyo } \\
\text { Clear }\end{array}$ & $\begin{array}{l}\text { Penicillin prior to } \\
\text { first clearance } \\
\text { Colomycin prior to } \\
\text { second clearing }\end{array}$ & $\begin{array}{l}\text { Cleared } \\
\text { Reinfected } \\
\text { Cleared }\end{array}$ \\
\hline 4. W. M. & $\begin{array}{c}17.10 .62 \\
\text { to } \\
27.3 .63\end{array}$ & $\begin{array}{l}\text { Pyo; Proteus; } \\
\text { Prov; Entero }\end{array}$ & Mar. I963 & Infected & Aug. I 963 & Clear & $\begin{array}{l}\text { Last antibiotic } \\
\text { Kanamycin } \\
2 \mathrm{I} .6 .63\end{array}$ & Cleared \\
\hline 5. D. H. & $\begin{array}{l}22.9 .61 \\
\text { to } \\
20.4 .62\end{array}$ & $\begin{array}{l}\text { Aer; Pyo; } \\
\text { Proteus }\end{array}$ & Dec. I96I & Infected & May i 964 & Clear & Nil & Cleared \\
\hline 6. W. S. & $\begin{array}{l}5.2 .63 \\
\text { to } \\
5.7 .63\end{array}$ & E. coli, Entero & Apr. 1963 & Clear & July 1964 & Clear & $\begin{array}{l}\text { Last antibiotic } \\
\text { Kanamycin } \\
23.6 .63\end{array}$ & Cleared \\
\hline 7. P. M. & $\begin{array}{c}1.6 .62 \\
\text { to } \\
27.2 .63\end{array}$ & $\begin{array}{l}\text { Proteus; Pyo } \\
\text { Entero; E. coli }\end{array}$ & Nov. 1962 & Clear & $\begin{array}{l}\text { Dec. } 1962 \\
\text { to } \\
\text { Feb. } 1963\end{array}$ & $\begin{array}{l}\text { Nil or } \\
\text { trivial }\end{array}$ & $\begin{array}{l}\text { Penicillin } \\
\text { Dec. } 1962\end{array}$ & Cleared \\
\hline 8. K. & $\begin{array}{c}1.3 .63 \\
\text { to } \\
30.8 .63\end{array}$ & $\begin{array}{l}\text { Staph; Pyo; } \\
\text { Proteus }\end{array}$ & July 1963 & Clear & Mar. 1964 & Clear & $\begin{array}{l}\text { Last antibiotic } \\
\text { Kanamycin } \\
\text { May } 1963\end{array}$ & $\begin{array}{l}\text { Cleared for } 12 \text { months; } \\
\text { reinfected } \\
\text { Myelomatosis and atonic } \\
\text { bladder }\end{array}$ \\
\hline 9. U. & $\begin{array}{l}\text { II. } 8.6 \mathrm{I} \\
\text { to } \\
3.2 .62\end{array}$ & $\begin{array}{l}\text { Proteus; Pyo; } \\
\text { Aer }\end{array}$ & Nov. 1961 & Clear & June 1962 & Clear & $\begin{array}{l}\text { Chloromycetin } \\
\text { Sept. I } 96 \text { I followed } \\
\text { by Crystamycin } \\
\text { Sept. I } 961\end{array}$ & Cleared \\
\hline ro. M. & $\begin{array}{l}10.7 .61 \\
\text { to } \\
30.3 .62 \\
2.5 .63 \\
\text { to date }\end{array}$ & $\begin{array}{l}\text { Aer; Pyo; } \\
\text { Proteus }\end{array}$ & Oct. I $96 \mathrm{I}$ & Clear & $\begin{array}{l}\text { Oct. I } 961 \\
\text { Jan. } 1962 \\
\text { June I } 963\end{array}$ & $\begin{array}{l}\text { Clear } \\
\text { Clear } \\
\text { Staph }\end{array}$ & $\begin{array}{l}\text { Many different } \\
\text { antibiotics-- } \\
\text { Celbenin last }\end{array}$ & $\begin{array}{l}\text { Cleared } \\
\text { Reinfected } \\
\text { Readmitted for sores and } \\
\quad \text { carried indwelling } \\
\text { catheter } 1964\end{array}$ \\
\hline 11. A. M. & $\begin{array}{l}7.11 .62 \\
\text { to } \\
28.4 .63\end{array}$ & $\begin{array}{l}\text { E. coli, Aer; } \\
\text { Proteus }\end{array}$ & Mar. 1963 & Infected & $\begin{array}{l}\text { June } 1963 \\
\text { Dec. } 1963\end{array}$ & $\begin{array}{l}\text { Clear } \\
E . \text { coli }\end{array}$ & $\begin{array}{l}\text { Last antibiotic } \\
\text { Furadantin } \\
\text { Dec. } 1963\end{array}$ & $\begin{array}{l}\text { Cleared } \\
\text { Reinfected } \\
\text { Urethral fistula }\end{array}$ \\
\hline I2. J. & $\begin{array}{l}9.4 .62 \\
\text { to } \\
7.8 .63\end{array}$ & $\begin{array}{l}\text { Staph; Pyo; } \\
\text { Proteus; Aer; } \\
\text { Prov }\end{array}$ & Nov. 1962 & Clear & $\begin{array}{l}\text { Dec. } 1962 \\
\text { July I } 1963 \\
\text { (Scanty be } \\
\text { in M.S. } \\
\text { cells; } \mathrm{pH}\end{array}$ & $\begin{array}{l}\text { Clear } \\
\text { Clear } \\
\text { cteria } \\
\text {; no } \\
5 \cdot 3 .)\end{array}$ & $\begin{array}{l}\text { Last antibiotic } \\
\text { Kanamycin } \\
\text { Dec. I } 962\end{array}$ & $\begin{array}{l}\text { Cleared } \\
\text { Stones in bladder } \\
\text { diverticulum--removed } \\
\text { Sept. } 1962\end{array}$ \\
\hline 13. H. & $\begin{array}{l}19.4 .62 \\
\text { tJ } \\
26 . \times 1.63\end{array}$ & $\begin{array}{l}\text { Prov; Proteus; } \\
\text { Pyo; Staph }\end{array}$ & Sept. 1962 & Infected & Oct. 1963 & Clear & $\begin{array}{l}\text { Crystamycin } \\
\text { Sept. I } 962\end{array}$ & Cleared \\
\hline
\end{tabular}


mycin. This would be most likely to succeed where a catheter was no longer required and the chance of reinfection diminished.

In view of the fact that in the test-tube $B$. providencia showed higher resistance to alkali than $B$. proteus it might have been expected to replace the latter when it had given rise to a urine of high $\mathrm{pH}$. The replacement of a proteus by a providencia strain was not often observed, however.

\section{DISCUSSION}

The four charts selected from the others and reproduced illustrate a number of the conclusions suggested by the observations recorded in this paper.

No. I and 2 illustrate a good and a bad result following treatment with indwelling catheter. In the case of W. F. the bladder was rapidly trained to natural voiding after stimulation and the catheter was withdrawm. Very soon thereafter his pyocyaneus and other infection disappeared.

Removal of the catheter has not been possible for the patient J. McI. and there has been a succession of different infections over a period of more than four years notwithstanding the use of many antibiotics. The pyocyaneus infection detected repeatedly in this patient's urine between November I960 and March I96I disappeared soon after a ten-day course of Polymyxin B methane sulphonate and was not again observed in the course of the ensuing three years although more than 20 careful examinations were made for it in that period. It reappeared, however, in February 1964. The findings in this case as in many others indicate the frequency of cross-infection in wards in which paraplegics are nursed.

Charts 3 and 4 illustrate again a good and a bad result. In these cases, however, two young lads were kept free from coliform infection for 12 and I5 weeks respectively on daily change of catheter combined with urethral antibiotic irrigation. D. W. contracted an aerogenes infection 13 weeks after injury but it was not till this infection had persisted for four weeks that the appearance of casts in the urine following a sharp spike of fever suggested the development of pyelonephritis. This infection, however, responded well to chloromycetin and he ultimately made an excellent recovery with a urinary tract free from infection.

R. A. contracted a combined pyocyaneus and proteus infection I6 weeks after injury. Within a week of this infection the patient developed high fever and was passing a urine loaded with casts which were studded with polymorphonuclear leucocytes. The proteus infection was apparently eliminated by a course of Kanamycin, but the pyocyaneus infection persisted for months. The patient still has an infected urinary tract and his general progress has been most disappointing.

These two cases support the conclusion about the relative importance of different types of infection reached from consideration of the whole group of cases.

\section{CONCLUSION}

It is generally agreed that the presence of an indwelling catheter in the urethra for a week or more is invariably associated with infection of the urinary tract and that for many paraplegics the sequel to this is pyelonephritis and ultimate failure of kidney function. It is also generally agreed that cure of established infection is very difficult while the catheter remains in position. It follows, therefore, that elimination of infection should be achieved if at all possible and that the most hopeful way of doing so is to eliminate the indwelling catheter. 
Some success in this respect has been attained under Dr. Guttmann's system of intermittent catheterisation and also in our hands by combining daily change of catheter and antibiotic urethral irrigation. Such procedures are time-consuming and will require an increase in highly trained personnel. They are, however, well worth further study and development if the present unsatisfactory state of affairs is to be remedied. This is that wards devoted to the care of paraplegics or other patients who require indwelling catheters tend to become hotbeds of infection with the bacteria most capable of causing severe damage in the urinary tract. These are the proteus and pseudomonas species; and patients newly admitted, even if entering free from urinary tract infection, too often become victims of these infections.

\section{ACKNOWLEDGMENTS}

This investigation was initiated and carried on for three years under a grant from the Scottish Hospitals Endowment Research Trust, and has been completed in the last year with the help of grants from the Medical Research Council and the Royal Society, and the Board of Management for the Astley-Ainslie, Edenhall and Associated Group of Hospitals. To these bodies we are much indebted.

We must also express our thanks to Dr. J. T. R. Russell for accommodation and facilities at Edenhall Hospital and to Mr. W. G. Kerr for his interest and advice, and latterly to Dr. J. C. Gould for laboratory facilities at the Western General Hospital, Edinburgh.

At an earlier stage in the investigation we have depended on and are grateful for the help of Mr. J. B. Arnot, Dr. A. J. W. Fordyce and Dr. M. McKinnon.

We are also much indebted to Sister A. Hume and Mr. J. Dunsire for excellent cooperation in the wards at Edenhall and in the laboratory we have had the benefit of much painstaking and patient work from Mrs. P. E. Strong, Mrs. A. A. Pilley and Mr. D. Henry in the preparation of charts and analysis of results. These also we thank very cordially.

Finally, we are indebted to Mr. C. Shepley for putting the charts into form suitable for reproduction.

\section{RÉSUMÉ}

Il est généralement admis que la présence d'une sonde à demeure dans l'urètre, pendant une semaine ou davantage, est inévitablement associée à une infection des voies urinaires, et pour beaucoup de paraplégiques, suivie de pyélonéphrite et, ultérieurement d'une détérioration terminale de la fonction rénale.

Il est aussi également admis que la guérison de cette infection urinaire est très difficile tant que la sonde est présente, le retrait de celle-ci pouvant, si cela est possible, permettre la stérilisation des urines.

Un certain succès dans ce domaine a été obtenu gràce à la méthode de sondage intermittent du Dr. Guttmann, ainsi que dans notre service, en combinant un changement journalier de la sonde avec des irrigations urétrales par antibiotiques. De tels procèdés demandent beaucoup de temps, et doivent être effectuées par un personnel très qualifié. Si l'on doit remédier à l'état actuel des choses, qui n'est pas satisfaisant, ils demanderaient à être perfectionnés et ultérieurement développés.

Les salles destinées à recevoir les paraplégiques ou autres malades porteurs des sondes à demeure, tendent à devenir de véritables foyers d'infections urinaires à germes très pathogènes particulièrement le proteus et les souches de pseudomanas. Les malades qui y sont récemment admis, même sans infection urinaire, en deviennent les victimes.

\section{ZUSAMMENFASSUNG}

Es ist allgemein bekannt, dass ein Dauerkatheter für eine Woche oder länger eine Infektion der Harnwege unvermeidlich macht. Dies führt bei vielen Paraplegikern zu Pyelonephritis und schliesslich zu letaler Schädigung der Nierenfunktion.

Es wird auch zugegeben, dass, solange der Dauerkatheter verwendet wird, Beseitigung der Infektion sehr schwierig ist, dass aber, wenn der Katheter entfernt werden kann, Sterilität des Urins möglich wird. 
Dr. Guttmann's Methode der intermittierenden Katheterisierung war in manchen Fällen erfolgreich und so war auch bei uns die Kombination eines täglichen Katheter Wechsels mit urethraler Irrigation mit Antibiotica. Diese Methoden sind zeitraubend und setzen ein sehr trainiertes Personal voraus. Aber Ihr Studium und Entwicklung sind wünsckenswert, um eine Besserung der augenblicklichen unbefriedigenden Situation zu erzielen. Zur Zeit bilden Paraplegiker Krankenzimmer, wo Dauerkatheter verwendet werden, Brutstätten von Bakterien, z. B. Proteus und Pseudomonas, denen Patienten, insbesondere frische Fälle, nur zu oft zum Opfer fallen.

\section{REFERENCES}

AIrd, I. (1957). A Companion in Surgical Studies, 2nd ed., p. I098. Edinburgh: Livingstone.

BADENOCH, A. W. (1958). Textbook of British Surgery, Chapter on Genito-Urinary Surgery, Vol. III, p. I. Souttar and Goligher.

Bailey, H. \& Love, MCN. (I962). A Short Practise of Surgery, I2th ed., p. I I29. London: Lewis.

Braude, H. \& McLeod, J. W. (Unpublished.)

BroOKE, M. S. (I95I). Acta path. microbiol. scand. 29, I.

Brown, Geraldine W. (I952). Med. F. Aust. 2, 658.

Brumfitt, W., Davies, B. L. \& Rosser, E. (I96I). Lancet, 2, 1059.

Christensen, W. B. (I946). F. Bact. 52, $46 \mathrm{I}$.

Colley, E. W. \& Frankel, H. L. (1963). Brit. med. F. 2, 790.

Colley, E. W. \& Frankel, H. L. (I964). Paraplegia, 2, I32.

COMARr, A. J. (I96I). J. Urol. 85, 983.

Comarr, A. J., Kawaichi, G. K. \& Bors, E. (I96I). Proc. Ioth Annual Clinical Spinal Cord Injury Conference, Veterans' Administration Hospital, Cleveland, Ohio, p. I.

Damanski, M. (1963). Paraplegia, I, I 49.

DAMANSKI, M. \& GibBon, N. (I956). Brit. F. Urol. 28, 24.

D’Anonzio, G. (I959). Proc. 8th Annual Clinical Spinal Cord Injury Conference, Aug. 25 , p. I.

Dick, T. B. S. (1952). Brit. F. Urol. 24, ro I.

DutTon, A. A. C. \& Ralston, MARY (I957). Lancet, I, I I5.

Frankel, H. L. \& Colley, E. W. (1963). Paraplegia, I, 200.

GibBon, N. (I958). Brit. F. Urol. 30, I.

Gould, J. C. \& McLeod, J. W. (I960). F. Path Bact. 79, 295.

Guttmann, L. (I953). In Cope, Sir Zachary, History of Second World War, Volume on Surgery, Chapter on Spinal Injuries, p. 462.

Guttmann, L. (I957). Bull. post-grad. Comm. Med. Univ. Sydney, r3, 27.

Guttmann, L. (196i). Medical Annual, p. 25. Bristol: Wright

HANDFIEld-Jones, R. M. \& PorRitT, Sir ARthur (I957). Essentials of Modern Surgery, 5th ed., p. 779. Edinburgh: Livingstone.

Houghton, B. J. \& Pears, M. A. (I957). Brit. med. F. I, 622.

Kass, E. H. (1955). Amer. F. Med. 18, 764.

Kass, E. H. \& Sossen, H. S. (I959). F. Amer. med. Ass. 169, I I8I.

Kaufmann, F. (I95I). Enterobacteriaceae, Ist ed. Copenhagen: Munksgaard.

Kaufmann, F. (1954). Enterobacteriaceae, 2nd ed., p. 317. Copenhagen: Munksgaard.

Kimmelstiel, P., Kim, On Ja, Beres, J. A. \& Wellman, K. (i96i). Amer. F. Med. 30, 589.

McDonald, R. A., Levitin, H., Mallory, G. K. \& Kass, E. H. (I957). New Engl. F. Med. 256, 915 .

MCLEOD, J. W. (I958). Lancet, I, 394.

Mcleod, J. W., Mason, J. M. \& Pilley, Alison, A. (I963). Lancet, I, 292.

McLeod, J. W. \& TAYlor, Margaret M. (I963). Scot. med. F. 8, 234.

Milner, P. F. (1963). F. Clin. Path. 16, 39.

Morales, P. \& Tsou, A. Y. (I962). F. Urol. 87, I9I.

Murnaghan, G. F. (I96I). Thesis for M.S., pp. I70-I77. University of Edinburgh.

Prescott, L. F. \& Brodie, D. E. (I964). Lancet, 2, 940.

Pryles, C. V., Luders, D. \& Alkan, M. K. (I96i). Pediatrics, 27, 17.

Pyrah, L. N., Goldie, W., Parsons, F. M. \& Raper, F. P. (I955). Lancet, 2 , 3 I4.

Riches, E. W. (1955). Lancet, 2, 507. 
Ridge, L. E. L. \& Thomas, M. E. M. (I955). F. Path. Bact. 69, 335.

Rose \& CARless (1960). In Wakeley, Sir Cecil, Farmer, M. \& TAYlor, S. Manual of Surgery, 19th ed., p. I246. London: Baillière.

Sanford, J. P., Favour, C. B., Mao, F. H. \& Harrison, J. H. (I956). Amer. F. Med.20, 88.

Scott, T. G. (1960). F. Clin. Path. 13, 54.

SiNGER, J. \& BAR-ChaY, J. (I954). f. Hyg. (Lond.) 52, I.

Stol, T. (1945). Helv. chir. Acta. 12, 638.

Stuart, C. A., Wheeler, K. M., Rustigian, R. \& Zimmermann, Alice. (i943). F. Bact. 45, IOI.

Stuart, C. A., Van Stratum, Elizabeth, \& Rustigian, R. (i945). F. Bact. 49, 437.

StuART, C. A., WheEler, K. M. \& McGanN, Virginia (I946). F. Bact. 53, 43 I

TAGART, R. E. B. (1956). Lancet, 2, 572.

Talbot, H. S. \& Romsey, E. J. (1955). Proc. 4th Annual Clinical Paraplegia Conference, Oct. I9, p. 28.

Williams, D. I. (1963). Brit. F. Urol. 35, 4I I. 